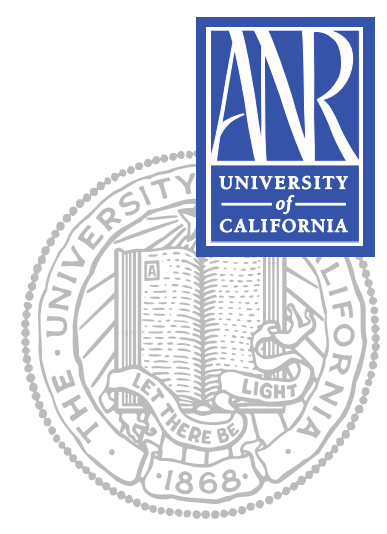

UNIVERSITY OF CALIFORNIA

Division of Agriculture and Natural Resources http://anrcatalog.ucdavis.edu

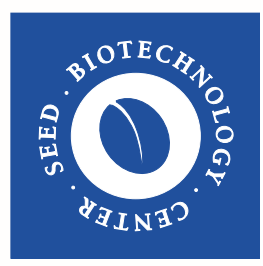

Produced by

Seed Biotechnology Center, UC Davis http://sbc.ucdavis.edu

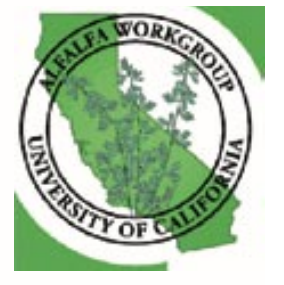

UC Alfalfa and Forages Workgroup http://alfalfa.ucdavis.edu

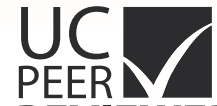

REVIEWED

\section{Roundup Ready Alfalfa: An Emerging Technology}

ALLEN VAN DEYNZE, Biotechnology Specialist, Seed Biotechnology Center, University of California, Davis; DANIEL H. PUTNAM, University of California Cooperative Extension Alfalfa Specialist, University of California, Davis; STEVE ORLOFF, University of California Cooperative Extension Farm Advisor and County Director, Siskiyou County; TOM LANINI, Cooperative Extension Weed Specialist, University of California, Davis; MICK CANEVARI, University of California Cooperative Extension Farm Advisor and County Director, San Joaquin County; RON VARGAS, University of California Cooperative Extension Farm Advisor and County Director, Madera and Merced Counties; KURT HEMBREE, University of California Cooperative Extension Farm Advisor, Fresno County; SHANNON MUELLER, University of California Cooperative Extension Farm Advisor, Fresno County; LARRY TEUBER, Professor, University of California, Davis

\section{INTRODUCTION}

Glyphosate-resistant crops, also known as "Roundup Ready" (RR), have become an important part of cropping systems in the United States. In 2004, approximately 13 percent of corn, 85 percent of soybean, and 60 percent of cotton acreage was occupied by RR varieties. Alfalfa (Medicago sativa) is the nation's third most important crop in economic value, and it occupies more than 22 million acres ( 8.9 million ha) in the United States (USDA 2004). It is considered the premier forage crop. It is the primary feed for dairy production, and is commonly fed to beef cattle, sheep, and horses. Alfalfa is also used for greenchop and silage in many areas. California is the leading producer of alfalfa hay in the United States, followed by Wisconsin, South Dakota, Minnesota, and Idaho. Roundup Ready technology has been successfully incorporated into alfalfa and is scheduled for commercial release in 2005. This publication reviews the important attributes and issues pertaining to RR technology as applied to alfalfa and the potential impacts of this technology on production systems and markets.

\section{What Is Roundup Ready Alfalfa?}

Roundup (glyphosate) is a broad-spectrum herbicide that kills a wide range of plants. It is not normally applied directly to crops. The RR technology incorporates genetic resistance to glyphosate into crop plants by inserting a single bacterial gene that modifies 5-enolpyruvylshikimate-3-phosphate (EPSP) synthase, an enzyme essential for plant growth. Monsanto has used this technology to develop several RR crops (e.g., cotton, soybeans, and corn).

Roundup Ready technology will enable the development of new weed control strategies for alfalfa. Specifically, these new varieties will allow glyphosate (for example, Roundup UltraMax-see label for the full spectrum of weeds controlled and application specifications) to be applied over the top of the entire crop to control a wide spectrum of annual and perennial weeds commonly found in alfalfa. Several of these weeds, especially perennials, are difficult to control using conventional herbicides or nonherbicide weed control methods. Although scientists at Monsanto and Forage Genetics International have developed the technology, RR alfalfa varieties will be marketed broadly by a wide range of seed companies. Important characteristics, such as genetic resistance to insects and diseases and yield potential, remain important criteria for selecting a variety. The RR trait enables a unique weed control program to be used in alfalfa. 


\section{ROUNDUP READY WEED CONTROL STRATEGIES}

\section{Importance of Weed Control in Alfalfa}

Successful weed control has been a continual challenge for alfalfa producers. The high forage quality requirements of the dairy industry in many areas necessitate nearly perfect weed control. In some regions, growers simply tolerate weed problems due to their inability to effectively control them. Similarly, it is important for the horse industry to have alfalfa hay that is free of noxious, low-quality, and poisonous weeds. This can be difficult with conventional herbicides. Typically no single herbicide controls all the weeds present in many alfalfa fields.

Weed management in alfalfa involves two distinct phases: weed control in seedling alfalfa during crop establishment and weed control in established stands. Weed infestation during crop establishment increases weed seed reserves and reduces seedling vigor and alfalfa stand, which can affect crop production for many years in this perennial crop. However, if protected from initial weed competition, a vigorous alfalfa stand competes well with later-invading weeds. After the crop is established, alfalfa stands naturally thin over years, making the crop increasingly susceptible to weed invasion. Weeds may reduce alfalfa yield, but more importantly, weeds reduce the forage quality of alfalfa. Most weeds are lower in forage quality or palatability than alfalfa. Therefore weeds can significantly reduce the feeding value of hay for milk production and affect animal growth and health. Weeds such as lambsquarters (Chenopodium spp.) and pigweed (Amaranthus spp.) can accumulate toxic nitrate concentrations. Others such as common groundsel (Senecio vulgaris) and fiddleneck (Amsinckia spp.) are poisonous to livestock and have been known to harm or even kill animals that feed on them.

\section{Stand Establishment Trials}

In 2002 to 2004, field trials were established in the intermountain area (spring- and fallseeded), Sacramento Valley, and two locations in the San Joaquin Valley of California to compare the RR weed management system with standard weed control strategies under the diverse environmental conditions and weed spectrums encountered in California. Different Roundup rates, 1 (1.12 kgha) and 2 pounds (2.24 kgha) active ingredient (a.i.) per acre, and application timings were evaluated and compared with conventional standards. Three different herbicide application timings were evaluated based on the alfalfa leaf stage: unifoliolate to first trifoliolate, 3 to 4 trifoliolate, and 6 to 9 trifoliolate. The conventional standards used varied slightly depending on the location and the weed spectrum but included Raptor (imazamox), a tank mix of Pursuit (imazethapyr) and Buctril (bromoxynil) or Prism (clethodim), and a tank mix of Roundup and Pursuit. Sequential treatments (when deemed necessary) were evaluated to ascertain the need for multiple treatments to control weeds that emerged after the initial application.

\section{Crop Injury and Seedling Mortality}

The Roundup treatments usually caused no injury. In cases where slight injury was observed, symptoms were short-lived and not evident at the time of first cutting. Raptor and Pursuit plus Buctril tank-mix treatments resulted in higher injury ratings, usually less than 20 percent at most locations. (Seedling mortality is not the same as early crop injury in RR alfalfa.) We observed a small percentage of seedling mortality in our RR alfalfa plots after the initial Roundup application. This is normal. Due to the polyploid genetics of the crop (similar population effects are observed for other traits in alfalfa), a small percentage of alfalfa seedlings do not contain the gene for Roundup resistance. Plant breeders from Forage Genetics International have indicated that seedling mortality of RR alfalfa varieties from commercial seed will likely be between 3 and 7 percent. This is not a problem with alfalfa, since usually more than 40 percent of seed sown fail to establish before the first or second cutting in a normal process of self thinning during stand establishment. However, 
if RR lines are not sprayed with Roundup during the seedling phase, these nonresistant plants may have a greater impact on the stand if sprayed at a time when the overall population is much lower (for example, after 6 months or a year after seeding). Therefore, it will be important to spray RR varieties at the 3 to 4 trifoliolate stage. Since one of the major incentives to plant RR alfalfa is to control weeds during establishment, this requirement should not be problematic for growers.

\section{Herbicide Efficacy during Stand Establishment}

Roundup applied at the proper alfalfa growth stage provided better than 95 percent control of nearly all weeds at all sites. Successful control of volunteer oats and wild radish in alfalfa using RR alfalfa and Roundup is shown in figure 1. Weeds controlled in the California experiments included:

- annual bluegrass (Poa annua)

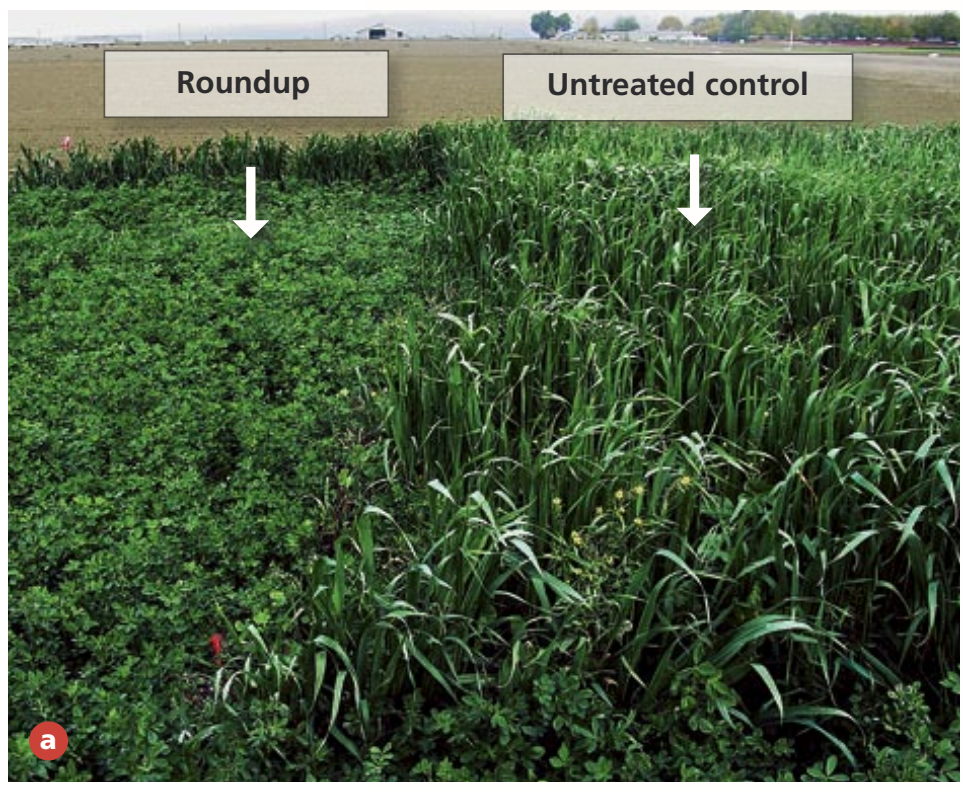

- chickweed (Stellaria media)

- common groundsel (Senecio vulgaris)

- kochia (Kochia scoparia)

- nightshade (Solanum spp.)

- prickly lettuce (Lactuca serriola, see fig. 2)

- purslane (Portulaca oleracea)

- shepherd's purse (Capsella bursa-pastoris)

- swinecress (Coronopus squamatus)

- volunteer oats (Avena fatua)

- volunteer wheat (Triticum aestivum)

- wild radish (Raphanus raphanistrum)

Roundup was less effective than other herbicides on henbit (Lamium amplexicaule). While the 2.0 pounds active ingredient per acre rate $(2.24$ $\mathrm{kg} / \mathrm{ha}$ ) of Roundup resulted in more rapid weed kill, it was generally not needed for most weeds. The broad-spectrum efficacy of Roundup is well known by weed scientists, since it has been in use for decades. Roundup is one of the most-studied herbicides used in agriculture.



Figure 1. Efficacy of Roundup in seedling stands of alfalfa on volunteer oats (a, photo by Ron Vargas) and on wild radish (b, photo by Mick Canevari).

\section{Timing of Application during Stand Establishment}

The importance of application timing during alfalfa seedling development varied depending on weed species, location, and time of year. Generally, our trials showed that when Roundup was applied at the 3 to 4 trifoliolate stage, weeds were effectively controlled and usually no second application was needed. Early applications allowed late germination of weeds, requiring a second application, while later applications (6 to 9 trifoliolate) allowed greater weed competition at early growth stages.

Roundup does not have soil residual activity, and weeds may emerge after application, especially if the alfalfa is small. At the intermountain 
site, a Roundup application made at the unifoliolate to first trifoliolate timing resulted in subsequent invasion of prickly lettuce (see fig. 2), and henbit, but shepherd's purse was completely controlled, as there was no subsequent emergence of this weed after the initial application. A second application in late winter was needed to control all the weeds. Similarly, a second application of Roundup was needed at one of the San Joaquin Valley sites (Five Points) when the first Roundup application occurred at the cotyledon to unifoliolate stage in alfalfa. Early Roundup timing resulted in excellent weed control in the other trials. In the San Joaquin County trial, where all Roundup timings performed well, a second flush of annual bluegrass and canarygrass (Phalaris minor) germinated in all treatments by early December. None of the conventional herbicide treatments controlled this second flush of weeds at this location, whereas a second application of Roundup was effective. The effectiveness of an early treatment appears to be a function of the weed species and its germination period and how soon after application the alfalfa canopy covers the soil surface.

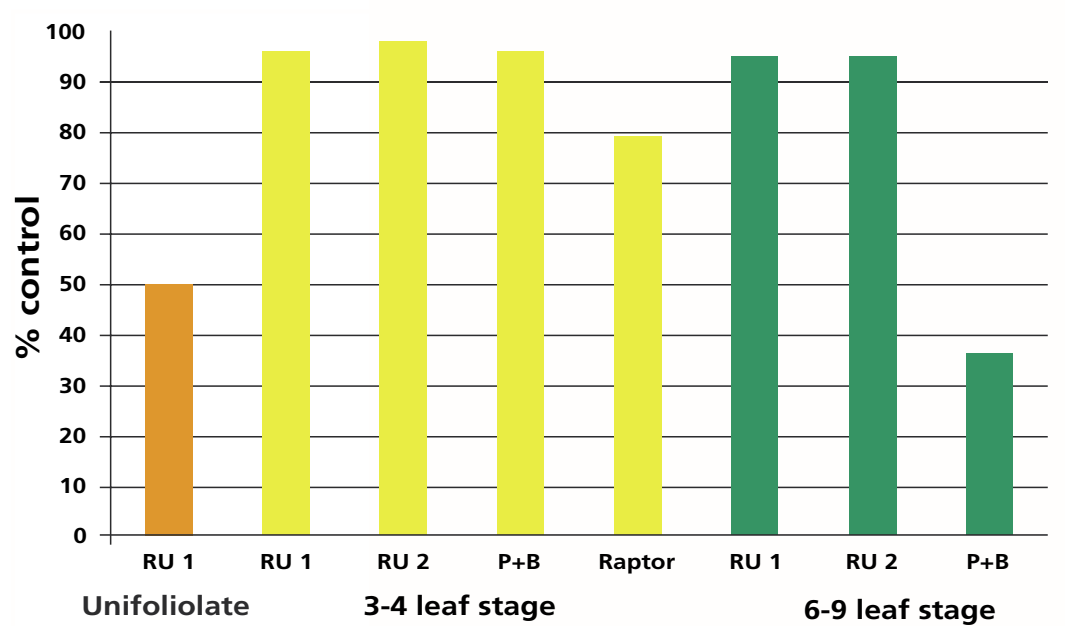

Figure 2. Prickly lettuce control with Roundup at different rates $(1 \mathrm{lb}$ and $2 \mathrm{lb}$ a.i./acre [1.12 and $2.24 \mathrm{~kg} / \mathrm{ha}$ ]) and timings (unifoliolate, 3 to 4 trifoliate, and 6 to 9 trifoliate stages) compared with commercial standards, Tulelake, California. Results were similar for many other weed species and locations. $\mathrm{RU}=$ Roundup; $\mathrm{P}+\mathrm{B}=$ Pursuit and Buctril.
Unlike standard herbicides, Roundup controlled weeds in the latest application period, 6 to 9 trifoliolate leaf stage. This indicates a greater flexibility with Roundup compared with other options. However, weed competition was typically greater when weeds are allowed to compete with alfalfa as late as the 6 to 9 trifoliolate stage.

The RR system of weed management resulted in the best overall weed control of the treatments evaluated, and there was considerable flexibility in treatment timing. These results indicated that application of Roundup during the 3 to 4 trifoliolate stage is likely to result in the best control of emerged weeds. Extremely early applications, at the unifoliolate to first trifoliolate growth stage, are generally not advised because under some conditions subsequent weed invasion can occur since open areas in the young stand facilitate weed encroachment. The necessity of a second application depended on location, weed spectrum, and timing of the first application.

\section{Efficacy in Established Stands}

Field trials to study winter weed control in established alfalfa were also conducted at the same locations. In established stands, Roundup was compared with a commercial standard herbicide treatment for established alfalfa, Velpar (hexazinone) and paraquat. These are commonly used during the dormant period to control the winter complex of weeds that germinate during the rainy period in California. Roundup and the commercial standards were equally effective at most sites, providing excellent weed control. The commercial standards caused visible injury at some locations on both conventional and RR alfalfa. No injury was observed on RR plants from Roundup treatments. Roundup controlled the weeds at all sites except the San Joaquin County site, where burning nettle (Urtica urens), was not controlled (fig. 3). This weed is not on the Roundup label. Tank mixes of Velpar with Roundup or paraquat controlled all weeds, including burning nettle. Our research showed that for difficult-to-control weeds, such as dodder (Cuscuta spp.) or small cheeseweed (Malva neglecta), applications should be initiated earlier than with other weeds, followed by a second application 2 weeks later. Several herbicides offer an 


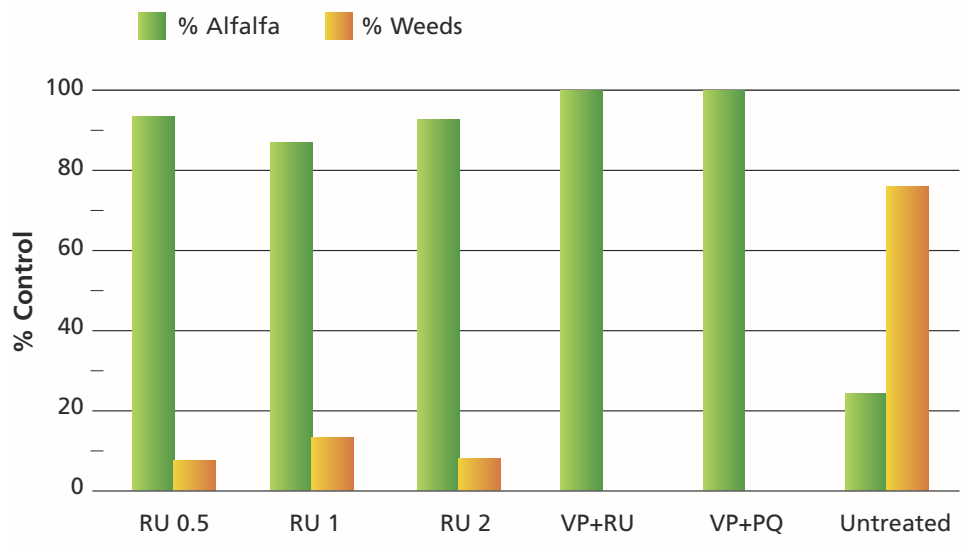

Figure 3. The effect of Roundup (RU at $0.5,1.0$ and $2.0 \mathrm{lb}$ a.i./acre [0.56, 1.12, and $2.24 \mathrm{~kg} / \mathrm{ha}]$ ), Velpar (VP), and Paraquat (PQ) treatments applied to established alfalfa stands in mid-December on the percentage of crop biomass in first-cutting alfalfa, April 2004, Tracy, California. The untreated treatment had annual sowthistle, chickweed, burning nettle, malva, and annual bluegrass. Burning nettle was not controlled by Roundup. alternative weed control strategy for herbicide rotations or tank mixes with Roundup if there are difficult-to-control weeds in the population.

\section{Removal of Roundup Ready Alfalfa Fields}

Eventually, an alfalfa stand must be removed when production falls to a level where the field is not as profitable or returns would be greater with a different crop. Roundup has been the primary herbicide used to remove depleted alfalfa stands; however, it obviously could not be used for this purpose in a field of RR alfalfa. The unwanted persistence of RR alfalfa in subsequent crops could potentially be a limitation of the technology if RR residual stands cannot be removed. However, alternative methods appear to be available to remove old RR alfalfa stands, but these methods must be adapted to specific crop-rotation situations.

Alfalfa fields are primarily removed by mechanical means such as cultivation with a plow or heavy disk or by undercutting the plants with a blade or rototiller. However, herbicides are sometimes used instead, alone or in combination with cultivation. Trials were conducted at several locations throughout California to evaluate the effectiveness of alternative herbicides for alfalfa stand removal. Numerous herbicides and herbicide combinations were tested including 2,4-D, Banvel (dicamba), Stinger (clopyralid), Garlon (tryclopyr), Liberty (glufosinate), Aim (carfentrazone), and Harmony (thifensulfuron methyl). Treatments containing 2,4-D and dicamba tended to be the most effective, generally controlling greater than 90 percent of the alfalfa with the least crop rotation restrictions (see labels for restrictions). Alfalfa control improved to nearly 100 percent with all herbicides evaluated when followed by cultivation. These results demonstrated that chemical and nonchemical alternatives to Roundup exist for alfalfa stand removal in RR fields (fig. 4).

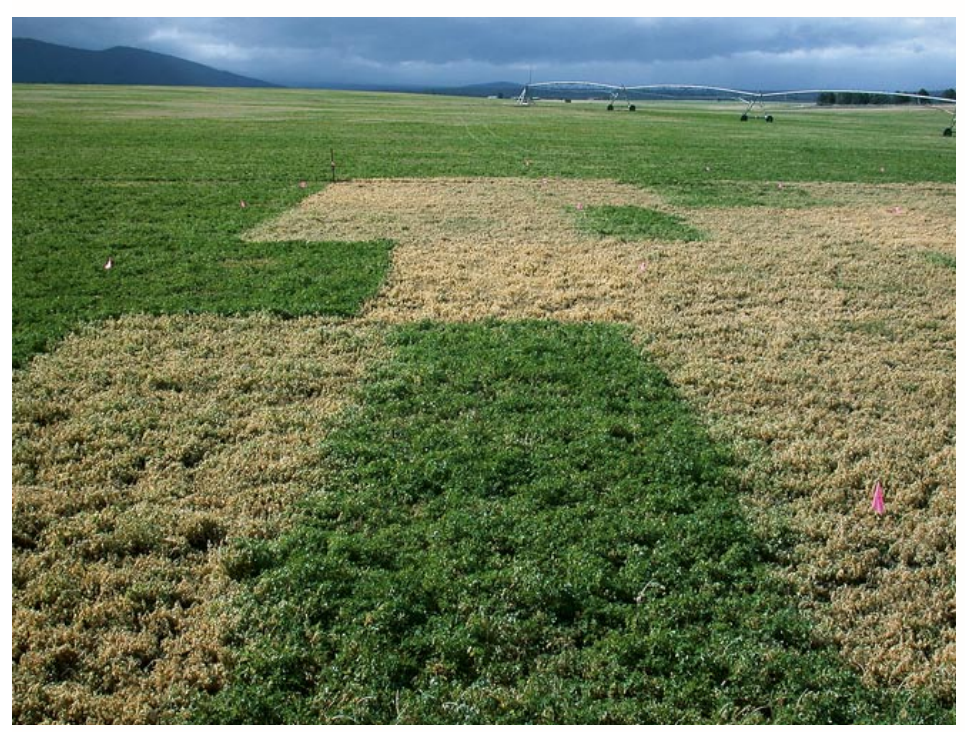

Figure 4. Overview of a herbicide trial showing treatments effective in removing established alfalfa stands in preparation for a following crop. Several herbicide treatments and tillage were effective at removing old alfalfa stands. Photo by Steve Orloff.

\section{SEED PRODUCTION OF ROUNDUP READY VARIETIES}

Alfalfa seed is grown primarily in the western United States on less than 100,000 acres (40,500 ha). Alfalfa is a cross-pollinated crop that requires bees to "trip" flowers to release pollen for seed production. In the United States, alfalfa seed production fields are pollinated with leafcutter bees (Megachile rotundata F.) in the Pacific Northwest and honey bees (Apis mellifera) in California. Some growers in Washington use alkali bees (Nomia melanderi C.) for pollination. Although viable seed production requires the transfer of pollen from one plant to another, control of pollen movement from seed field to seed field is important for maintaining genetic purity in alfalfa seed production, whether it is RR or not. Isolation standards are in place to maintain the purity of seed from varieties in adjacent seed fields. However, seed companies and alfalfa seed produc- 
ers will need to establish new or modified protocols for production of RR seed, since the seed may require higher standard of purity to address specific markets.

\section{Gene Flow and Seed Purity}

Understanding alfalfa outcrossing rate, gene flow, and pollinator behavior is very important to proper management of commercial alfalfa seed production. Current isolation standards for alfalfa in the United States are 165 feet $(50 \mathrm{~m})$ isolation from other alfalfa for certified seed and 900 feet $(274 \mathrm{~m})$ for foundation seed production. These are based on data collected in the 1980s, which used pest resistance genes as pollen flow markers between seed production fields (Brown et al. 1986). Recent studies used naturally occurring alfalfa marker genes to measure the potential for gene flow from source blocks to alfalfa plants at various distances from the source (St. Amand et al. 2000). This experiment was useful in studying the potential for transgene escape to feral alfalfa. A larger (1- to 2-acre [0.4- to 0.8-ha] source plot) 3-year study was carried out by Forage Genetics International using leafcutter bees. Both studies indicated that although gene flow can be detected over 1,500 feet $(457 \mathrm{~m})$ from the pollen source, it is reduced to less than 0.5 percent at 900 feet $(274 \mathrm{~m})$ and less than 0.2 percent at distances greater than 1,500 feet (see fig. 5; Fitzpatrick et al. 2003).

Preliminary studies conducted by University of California scientists in 2003 using honey bees as pollinators evaluated movement of the RR gene into herbicide-susceptible trap crops west and east of a 6-acre (2.4-ha) RR source plot at distances up to 2.5 miles $(4 \mathrm{~km})$. A significant decrease in gene flow with increasing distance from the source plot was observed (fig. 6). At 900 feet $(274 \mathrm{~m})$, pollen-mediated gene flow was less than 1.5 percent, and it decreased to less than 0.2 percent near 5,000 feet $(1.5 \mathrm{~km})$. Gene flow continued to decline to a distance of 2.5 miles $(4 \mathrm{~km})$, where it was detected at a very low frequency $(<0.03 \%)$. Gene flow to the west and the east was not significantly different. It is clear that pollen-mediated gene flow decreases exponentially with distance, and the safe distance to minimize pollen flow is affected by type of pollinator.

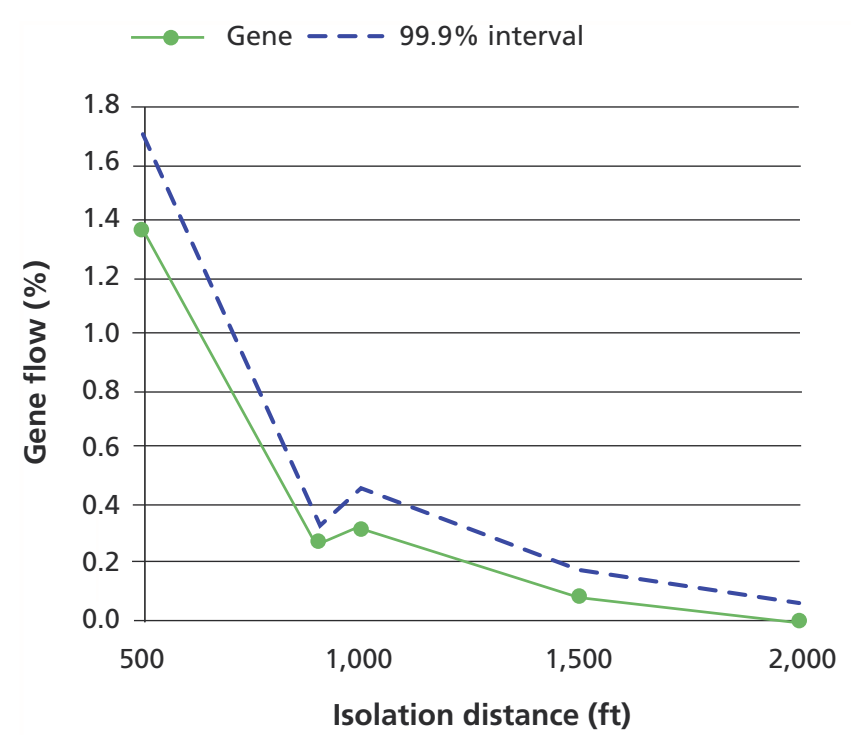

Figure 5. Gene flow between herbicide-resistant and conventional alfalfa using leafcutter bees as pollinators, Idaho, 2000 and 2001. Gene flow decreases to below $0.5 \%$ at 900 feet $(274$ $\mathrm{m})$. No gene flow was detected at 2,000 feet $(610 \mathrm{~m})$. The solid line is the percentage of gene flow and the dotted line is the upper 99.9 percent confidence interval.

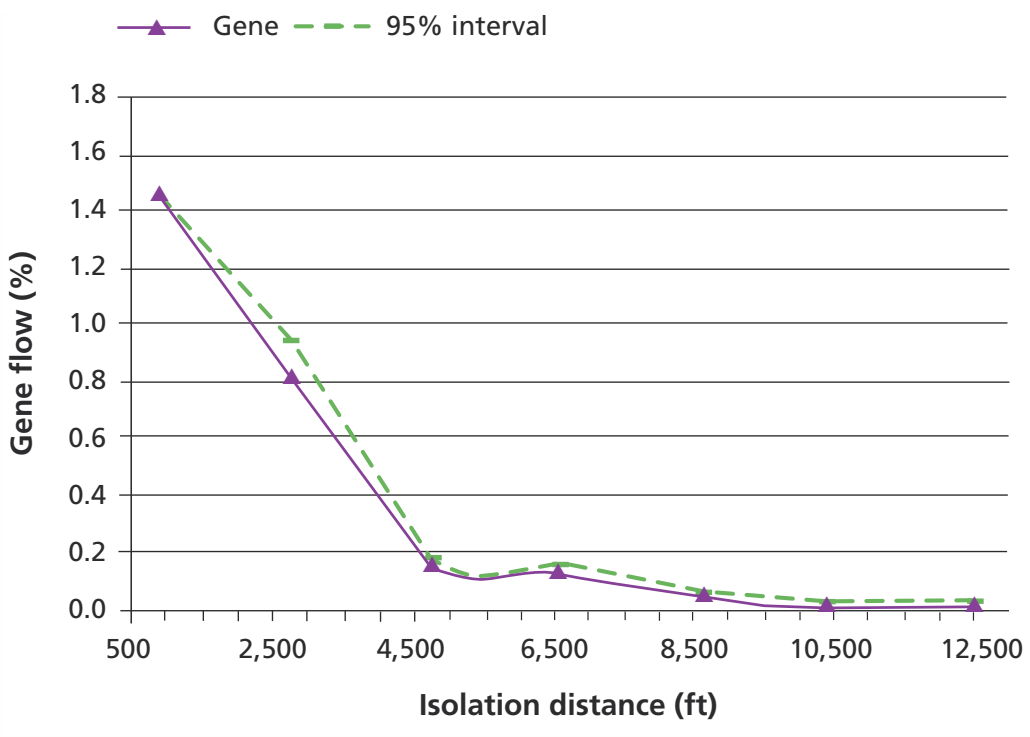

Figure 6. Preliminary data on gene flow between herbicide-resistant alfalfa and conventional alfalfa in California, 2003, using honey bees as pollinators. Gene flow decreases to below 1 percent at 2,500 feet (about $0.5 \mathrm{mi}$, or $0.8 \mathrm{~km}$ ). Sporadic gene flow $(<0.03 \%)$ can be detected up to 12,500 feet (about $2.5 \mathrm{mi}, 4 \mathrm{~km}$ ). The solid line is the percentage of gene flow and the dotted line is the upper 95.0 percent confidence interval. 


\section{Monitoring, Identification, and Quality Control}

The preliminary data from honey-bee-pollinated field studies will be combined with data from future studies to develop strategies to preserve seed trait quality during seed production. Crop isolation practices are being developed by seed companies and producers to ensure seed purity and a minimum adventitious presence (unintended presence of genetic traits) in conventional alfalfa seed and hay. Although currently there are no standards in the United States to separate government-approved biotechnology traits, 1 percent adventitious presence has been suggested as the standard for adventitious presence of biotechnology-derived traits in non-transgenic varieties of seed crops in export markets. Handling of RR alfalfa seed may also require additional checks in place to prevent co-mixing of transgenic and conventional seed, depending on the market destination of the seed. For a review of crop identity preservation, see Sundstrom et al. 2002.

\section{Variety Adaptation and Selection}

Hundreds of alfalfa varieties have been developed for use in North America using conventional breeding methods of crossing and selection. These varieties are adapted to the major alfalfa production zones and contain important genes for high yield, resistance to diseases, insects, and nematodes. Growers have been the beneficiary of decades of plant breeding by public institutions and private companies and competition between seed companies for their business. Several alfalfa seed companies will likely be marketing RR alfalfa varieties to satisfy a range of market conditions. Although Forage Genetics International has developed the initial RR alfalfa cultivars, other alfalfa breeding companies will have access to the trait. Fall dormancy (the genetic trait of fall and winter growth) is a major criterion for variety selection. In the first few years of release of the RR technology, the selection of varieties is likely to be limited to varieties within a small range of fall dormancies, with other fall dormancy classes to follow in subsequent years.

With the introduction of the RR trait, variety selection will include consideration of yet more "value-added" traits that should be considered in addition to yield and other traits. Generally, the protocol for selection of RR lines does not differ significantly from the selection of conventional lines. Fall dormancy group, yield potential, disease and insect resistance, and forage quality should all be considered, in addition to the value of the herbicide resistance. Calculations of potential benefits from the weed control technology should be compared to the added cost of the seed, relative costs of herbicide strategies, and potential limitations of the technology.

\section{Seeding Rates}

Recommendations for seeding rates vary significantly across the United States. California currently recommends a range of 15 to 25 pounds per acre (17 to $28 \mathrm{~kg} / \mathrm{ha}$ ) of seed, depending on seeding method and soil preparation. Although the price of seed is typically less than 2 percent of the total cost of production for growers, as the value and cost of seed increases, the relative economic impact of seeding rates and method increases. Precise seeding methods combined with proper soil preparation allow good control of seeding depth, seed placement, and soil-seed contact. Irrigation and early weed control during stand establishment reduce the probability of stand failure. These practices may enable growers to lower seeding rates, and thus manage cost of seed for higher-value genetics.

\section{POTENTIAL BENEFITS OF ROUNDUP READY ALFALFA}

\section{Enhancing Weed Control Options}

Current technology controls most but not all weeds. Certain weeds, such as Canada thistle (Cirsium arvense), dandelion (Taraxacum officinale), dodder, nutsedge, (Cyperus spp.) bermudagrass, (Cynodon dactylon), and quackgrass (Elytrigia repens L.) are particularly 
problematic. Annual weeds such as barnyardgrass (Echinochloa crusgalli), pigweed, lambsquarters, foxtails (Setaria spp.), nightshades, downy brome (Bromus tectorum L.), and mustards (Brassica spp.) can be troublesome at certain times. A subset of these weeds can be controlled by a combination of currently available herbicides in tank mixes or multiple applications, but Roundup controls a broader weed spectrum and may be more efficacious than most currently available herbicides or herbicide combinations (see the section "Roundup Ready Weed Control Strategies," above).

\section{Weed Control Flexibility}

While many available weed control options have fairly well-defined requirements and restrictions as to application timing, temperatures, and environmental influences, Roundup strategies are likely to provide a more-flexible option to growers. Although timing with Roundup applications is to some degree still important, it may not prove as important as it is with some of the alternative methods. The high degree of flexibility and broad-spectrum weed control are the principal benefits of RR alfalfa.

\section{Potential Economic Benefits}

Roundup Ready technology has the potential to provide more-reliable stand establishment and improve alfalfa yields and forage quality due to reduced weed contaminants. The value of alfalfa per ton may be improved, since pure alfalfa is usually worth 20 to 50 percent more than weedy hay. Other possible benefits include extended life of stands and improved crop safety compared to other weed control options. However, as of this writing, the economic benefits of the RR technology are not entirely clear, since the pricing structure has not yet been determined.

\section{Animal Feed Safety and Animal Health}

Contamination with poisonous, antinutritional, or simply unpalatable weed species is a common hazard of livestock feeding. Veterinary diagnostic labs and veterinarians each year report many cases of horses, cows, and sheep that are killed or sickened after consuming alfalfa that has been contaminated with such weeds. Some weeds simply lower animal performance or milk production, but others can kill. Roundup Ready alfalfa provides a simple option to minimize the risk of consumption of poisonous or unpalatable weeds by livestock, and it has the potential to improve animal welfare and production by increasing the feeding of pure, weed-free, high-quality alfalfa hay.

\section{Water Quality}

In addition to the benefits in terms of crop productivity, crop quality, animal production, and value, RR technology may replace some herbicides that have the potential to contaminate water supplies. Several herbicides used in alfalfa during the winter (dormant) period have been detected in wells in California's San Joaquin Valley (Troiano et al. 2001). To the extent that it replaces those options, RR technology could lessen this environmental concern, since there is little evidence of off-site environmental impacts from glyphosate (Thompson et al. 2004).

\section{Preventing Spread of Noxious Weeds}

Although all successful weed control strategies share this characteristic, RR alfalfa could improve the ability of growers to slow or stop the spread of noxious weeds in hay. The U.S. Forest Service and other agencies have encouraged the use of certified weed-free hay to be brought into natural areas for livestock and pack horses to prevent the spread of noxious weeds into environmentally sensitive areas. Roundup Ready technology could aid in that effort by creating "weed-free" alfalfa hay. 


\section{POTENTIAL PROBLEMS WITH ROUNDUP READY ALFALFA}

\section{Weed Control Limitations}

Although the spectrum of weeds controlled by Roundup is impressive, certain weeds are not completely controlled by Roundup. These include cheeseweed (Malva parviflora), burning nettle (Urtica urens), filaree (Erodium spp.), and others. In addition, Roundup has no residual activity that controls weeds for longer periods, as some conventional herbicides do. Roundup Ready technology should not be viewed as a panacea, but as a component of an overall weed control effort on a farm. Weed control strategies that incorporate cultural methods and rotation of herbicides will be needed to combat weeds not completely controlled by Roundup in order to prevent weed shifts.

\section{Herbicide Resistance}

One environmental concern about RR technology is the development of herbicide resistance in weed populations. This becomes more of a concern as the acre treated with Roundup increases. Since RR technology already encompasses many crops (corn, soybeans, cotton, oilseed rape), it is very likely that tens of millions of acres will be treated with Roundup each year nationally. Evidence for Roundup resistance has already been identified in natural populations in some species, such as ryegrass (Lolium spp.) (Powles et al. 1998) and horseweed (Conyza canadensis) (Rogers 2002). It is possible that this might occur in other species. This problem is not unique to Roundup but is common for other classes of herbicides as well. The development of weeds with resistance to Roundup is thought to be less likely than for other herbicides, as Roundup has no soil residual activity, and Roundup has a unique mode of action. Herbicide strategies that incorporate integrated cultural methods and rotations of herbicides are needed to prevent herbicide resistance. This is especially important to control volunteers of subsequent herbicideresistant crops.

\section{Weed Shift}

A weed shift is a change in the relative frequency of weeds in a population in response to a management practice. In the case of herbicides, weed shifts occur when a herbicide does not kill the entire weed spectrum encountered in a field. The density of the weed species that is not controlled increases over time, resulting in a weed shift. While Roundup is perhaps the most broad-spectrum foliar herbicide available, it is not equally effective on all weeds. Roundup is less effective for the control of many common weeds, such as cheeseweed, burning nettle, filaree, and purslane. Over time, if Roundup is used repeatedly as the only weed control measure, the prevalence of these weeds is likely to increase. This has already been observed in a trial in San Joaquin County, where burning nettle was not adequately controlled with Roundup (see fig. 4), and the population of this weed has increased significantly over a 3-year period. As with herbicide resistance, the best practice to prevent weed shifts is to avoid using the same herbicide year after year and to rotate herbicides and crops, as well as using nonherbicide strategies to control weeds.

\section{Gene Flow to the Environment}

As the RR gene is new to alfalfa, its effect on the environment must be studied in the context of gene movement and persistence in plants. Genes (DNA) introduced through biotechnology are passed on from generation to generation and to and from close relatives as any other gene in plants. Genes can be transferred among varieties or closely related species by gene flow or seed mixtures. It is important to establish strict management protocols to ensure varietal purity and minimize gene flow to and from unwanted sources, also known as adventitious presence. Gene flow is affected by sexual compatibility, flower characteristics, pollen viability and quantity, proximity of neighboring plants, pollinator activity, and environmental conditions. In the United States, there are no sexually compatible wild relatives to alfalfa; feral alfalfa is the only plant it can successfully cross with. 
The potential environmental impact of the gene flow from RR alfalfa to feral alfalfa must be understood in terms of "fitness." Alfalfa generally is not considered by weed scientists to be an invasive weed, but it does occur along roadside ditches (often sown by state and local highway managers) and in agricultural areas. If the RR gene is transferred to feral alfalfa, it is not clear that these plants would have any natural advantage over conventional alfalfa, or any greater weedy characteristics, except where Roundup is sprayed. Research is currently being conducted by University of California scientists to determine the proper weed management programs to prevent outcrossing and to control feral alfalfa. As our alfalfa removal studies have shown, several commercial herbicides are currently available for removal of RR alfalfa.

For the 22 million acres (8.9 million ha) of alfalfa in the United States, the issue of crossing RR alfalfa with feral relatives may not be a major issue, since these fields are typically harvested in the prebud to midflower stage of development, thus little pollen flows and few viable seeds are set (typically none). The issue of gene flow is primarily a concern in seed production, where pollen flow is necessary for seed set. Currently, less than 0.5 percent of the alfalfa grown in the United States is grown for seed.

\section{Market Acceptance of Roundup Ready Hay}

Roundup Ready alfalfa will be the first genetically enhanced alfalfa product to be marketed commercially. It is anticipated that the first commercial crops will be grown in 2005 . In most parts of North America, the majority of alfalfa is fed on-farm, but in the western United States, the majority of hay is offered for sale to dairy, with the remainder to horse, beef, and export customers. Nationwide, most alfalfa is consumed by the U.S. dairy industry, where it is considered the premier forage crop. For example, in California, dairy cows consume greater than 75 percent of the state's alfalfa crop. Thus, consumer acceptance of RR hay is highly dependent upon the acceptance of the dairy industry, which in the last decade has absorbed four to six new technologies related to genetically modified crops. Because of this, most experts believe that the dairy industry will, by and large, accept RR alfalfa. The horse industry may provide initial resistance, since individual preferences come to the forefront, but some buyers may be attracted to the "weed free" aspect of RR alfalfa. The organic market for hay is small and will likely reject RR alfalfa, as it does other biotech crops. Except for some specific markets such as organic, most alfalfa experts do not foresee significant market resistance to RR hay, with the exception of the export market.

\section{Exports}

The United States exports about 4 percent of its alfalfa to Japan, Korea, Taiwan, Mexico, and Canada. About 80 percent of U.S. alfalfa hay exports are destined for Japan (see http:// www.fas.usda.gov/ustrade), with approximately one-quarter shipped through California and three-quarters shipped through Oregon and Washington ports (see http://www.ams. usda.gov/lsmnpubs/PDF_Monthly/CALHAY2003.pdf). The majority of exported alfalfa is grown in the western states. Exporters in these states have expressed concern that their overseas customers may not accept the presence of a genetically modified crop. Export consumer preference may also be highly dependent on price. At a minimum, buyers will need to initially differentiate transgenic hay from nontransgenic hay in their export lots. It is likely that the tools and management practices to achieve this will be in place prior to commercialization. For example, sensitive tests to detect the presence of the RR gene in hay and seed are currently being developed.

Full approval by government agencies for animal feed and food in the United States and major export markets is currently being sought. The protein responsible for Roundup (glyphosate) tolerance has already been approved for feed and food use in other crops in the primary export countries. Roundup Ready alfalfa will not be commercialized until regulatory and safety approval is obtained in the United States and Japan, according to 
Forage Genetics International and Monsanto. The Japan Feed Trade Association stated in July 2002 that it had no concerns about RR alfalfa, since biotechnology-enhanced canola, soybeans, corn, and cottonseed have been used successfully for feed in that country.

\section{FOOD SAFETY}

The RR alfalfa system is currently being evaluated for safety in food, in feed, and in the environment. The safety of biotechnology-derived crops in food and feed is measured using the principle of substantial equivalence (FAO/WHO 1996). The idea is to compare feed and food from a biotech crop to its nearest nonbiotech counterpart that has a long history of being safe to consume. In this context, the effect of introduction of the new protein in feed or foods is studied for its toxicity, allergenicity, and any modifications in nutritional value in whole foods and feeds. The gene introduced in RR alfalfa is the same gene used to create other RR crops such as corn, soybeans, oilseed rape, and cotton. As a result, the impact of the introduction of this gene on ecological, environmental, and food and feed safety has been studied extensively for over 8 years since its initial large-scale introduction into soybeans in 1996 in the United States. These studies have shown that RR crops are substantially equivalent to conventional crops for their use as foods and feed (Hammond et al. 1996; Taylor et al. 2001). Dairy and beef cattle, swine, and poultry producers can currently feed alfalfa or other crops treated with Roundup. The United States Department of Agriculture, Environmental Protection Agency, and Food and Drug Administration regulate ecological, environmental, and food and feed aspects of biotechnology traits in the United States, respectively. Animal feeding studies are currently being conducted to evaluate any effects on growth, quality, and safety of RR alfalfa to livestock production. Roundup Ready alfalfa will not be commercialized until the EPA and FDA have concluded that it is substantially equivalent to conventional alfalfa based on safety data and residue studies (see Van Deynze et al. in press for review).

\section{SUMMARY}

Roundup Ready alfalfa is likely to be commercialized in 2005, contingent upon regulatory approval and logistical considerations. This technology combines the insertion of a gene conferring resistance to glyphosate in alfalfa varieties, enabling applications of the broad-spectrum herbicide Roundup or its equivalent. It is likely to expand weed control options available for alfalfa growers, potentially enhancing yield, forage quality, and profitability. Economic benefits will depend on pricing structures defined by the industry. There are potential environmental benefits if current herbicides present water quality or worker-safety concerns. The major concerns associated with RR technology are the potential for weed shifts, weed resistance, potential gene flow during seed production to feral alfalfa, stand removal, and market acceptance for exports. Management strategies to address these concerns have been suggested. Roundup Ready alfalfa is being extensively studied by public and private researchers to develop management protocols and address environmental questions for this technology. This technology provides an additional weed management tool for growers, the principal feature being its simplicity, flexibility, and broad-spectrum weed control.

\section{REFERENCES}

Brown, D. E., E. L. Grandstaff, M. R. Hanna, A. A. Hanson, V. L. Marble, and J. B. Moutray. 1986. Committee on alfalfa field isolation. Report of the 30th North American Alfalfa Improvement Conference. July 27-31, 1986.

FAO/WHO. 1996. Biotechnology and food safety. Rome: FAO. 1-27.

Fitzpatrick, S., P. Reisen, and M. McCaslin. 2003. Pollen-mediated gene flow in alfalfa: A threeyear summary of field research. Proceedings of the 2003 Central Alfalfa Improvement Conference, Virtual Meeting July 21-25, 2003. National Alfalfa Improvement Conference Web site, http://naaic.org/Meetings/Central2003/Gene_Flow_in_Alfalfa_Abstract_final.doc

Hammond, B. G., J. L. Vicini, G. Hartnell, M. W. Naylor, C. D. Knight, E. H. Robinson, R. L. Fuchs, and S. R. Padgette. 1996. The feeding value of soybeans fed to rats, chickens, catfish and dairy cattle is not altered by genetic incorporation of glyphosate tolerance. Journal of Nutrition 126:717-27.

Powles, S. B., D. F. Lorraine-Colwill, J. J. Dellow, and C. Preston. 1998. Evolved resistance to glyphosate in rigid ryegrass. Weed Science 46:604-7. 
Rogers, C. B. 2003. Glyphosate resistance in horseweed (Conyza canadensis) from a western Kentucky farm. In Proceedings of the Southern Weed Science Society 56:360. See http://www.weedscience.org/paper/SWSSabstract-Rogers\%202003.pdf.

St. Amand, P. C., D. Z. Skinner, and R. N. Peaden. 2000. Risk of alfalfa transgene dissemination and scale dependent effects. Theoretical and Applied Genetics 101:107-14.

Sundstrom, F. J., J. Williams, A. E. Van Deynze, and K. J. Bradford. 2002. Identity preservation of agricultural commodities. University of California Division of Agriculture and Natural Resources Publication 8077. ANR Communication Services Web site, http://anrcatalog.ucdavis.edu/pdf/8077.pdf.

Taylor, M. L., G. F. Hartnell, B. George, and J. D. Astwood. 2001. Comparison of broiler performance when fed diets containing YieldGard corn, YieldGard and Roundup Ready corn, parental lines, or commercial corn. Poultry Science 80:319.

Thompson, D. G., B. F. Wojtaszek, B. Staznik, D. T. Chartrand, and D. R. Stephenson. 2004. Chemical and biomonitoring to assess potential acute effects of Vision herbicide on native amphibian larvae in forest wetlands. Environmental Toxicology Chemistry 23:843-49.

Troiano, J., D. Weaver, J. Marade, F. Spurlock, M. Pepple, C. Nordmark, and D. Bartkowiak. 2001. Summary of well water sampling in California to detect pesticide residues resulting from nonpoint-source applications. Journal of Environmental Quality 30:448-59.

USDA. 2004. Acreage June 2004. USDA National Agricultural Statistics Service Web site, http://usda.mannlib.cornell.edu/reports/nassr/field/pcp-bba/.

Van Deynze, A., K. F. Bradford, and A. Van Eenennaam. 2004. Crop biotechnology: Feeds for livestock. University of California Division of Agriculture and Natural Resources Publication 8145. ANR Communication Services Web site, http://anrcatalog.ucdavis.edu/pdf/8145.pdf.

\section{FOR FURTHER INFORMATION}

To order or obtain printed publications and other products, visit the ANR Communication Services online catalog at http://anrcatalog.ucdavis.edu. You can also place orders by mail, phone, or FAX, or request a printed catalog of our products from:

University of California

Agriculture and Natural Resources

Communication Services

6701 San Pablo Avenue, 2nd Floor

Oakland, California 94608-1239

Telephone: (800) 994-8849 or (510) 642-2431, FAX: (510) 643-5470

E-mail inquiries: danrcs@ucdavis.edu

An electronic version of this publication is available on the ANR Communication Services Web site at http://anrcatalog.ucdavis.edu.

Publication 8153

(C) 2004 by the Regents of the University of California, Division of Agriculture and Natural Resources. All rights reserved.

The University of California prohibits discrimination or harassment of any person on the basis of race, color, national origin, religion, sex, gender identity, pregnancy (including childbirth, and medical conditions related to pregnancy or childbirth), physical or mental disability, medical condition (cancer-related or genetic characteristics), ancestry, marital status, age, sexual orientation, citizenship, or status as a covered veteran (covered veterans are special disabled veterans, recently separated veterans, Vietnam era veterans, or any other veterans who served on active duty during a war or in a campaign or expedition for which a campaign badge has been authorized) in any of its programs or activities.

University policy is intended to be consistent with the provisions of applicable State and Federal laws.

Inquiries regarding the University's nondiscrimination policies may be directed to the Affirmative Action/Staff Personnel Services Director, University of California, Agriculture and Natural Resources, 300 Lakeside Drive, $6^{\text {th }}$ Floor, Oakland, CA 94612-3550, (510) 987-0096. For information about obtaining this publication, call (800) 994-8849. For downloading information, call (530) 297-4445.

This publication has been anonymously peer reviewed for technical accuracy by University of California scientists and other qualified professionals. This review process was managed by the ANR Associate Editor for Pest Management.

To simplify information, trade names of products have been used. No endorsement of named products is intended, nor is criticism implied of similar products that are not mentioned. 